\title{
PENGATURAN PERIZINAN TOKO SWALAYAN SEBAGAI POTENSI PENDUKUNG KEPARIWISATAAN DI BALI
}

\author{
Oleh
}

\author{
I Nengah Suantra, Made Nurmawati, Desyanti Suka Asih K TUS \\ E-mail:nengah_suantra@unud.ac.id,nurma_unud@yahoo.com,d3sy_kurniatus@yahoo.com \\ Artikel ini merupakan luaran hasil penelitian unggulan program studi \\ Ilmu Hukum Fakultas Hukum Universitas Udayana mengenai Penerbitan Izin Usaha Toko Modern Sebagai \\ Potensi Pendukung Kepariwisataan di Bali Tahun 2017. \\ Dosen Fakultas Hukum Universitas Udayana. \\ Dosen Jurusan Hukum Fakultas Dharma Duta IHDN Denpasar.
}

\begin{abstract}
In Bali, quota of supermarkets are exceed and many are unlicensed. The purposes of this normative legal research are to analyze the issuance of the licenses and the existence of the illegal supermarkets. Research on the primary legal materials, secondary legal materials and tertiary legal materials are using statutory approach and conceptual approach. The legal materials are includes interview with the authority in the Law and Human Rights department, Trade Department, and Tourism Department in Kabupaten Tabanan, Badung, Klungkung and Kota Denpasar; inventoried, identified, interpreted, then presented in analytically descriptive. The regulation of supermarkets performed with local regulation, regent or mayor regulation, and mayor decree. However there are areas which have no regulation for supermarkets. The unlicensed supermarkets are more than the licensed supermarket. The unlicensed supermarkets allowed to operate the business because the licenses are in process, do not turn off businesses, and do not increase unemployment. However, it is developed, and who is disobey provided a written warning, some even close. Supermarkets are strongly support tourism because it is easy to find, easy to get the goods needed with more guaranteed quality, shop comfortably, safely and have certainty of price. The regulation of supermarkets are more precise with local regulation.
\end{abstract}

Key words: tourism, regulation, licenses, supermarkets.

\section{Pendahuluan}

Di wilayah Provinsi Bali toko swalayan tumbuh sangat pesat hingga ke pedesaan, bahkan saling berhimpitan dengan usaha mikro, kecil, dan menengah (UMKM). Keberadaan toko swalayan belum tertata dan terkoordinasi dengan baik sehingga terdapat banyak yang tidak berizin dan melebihi kuota. Di Kabupaten Badung jumlah toko swalayanmelebihi kuota yaitu $1.760 .{ }^{1} \mathrm{Di}$ Karangasem terdapat paling sedikit 7 (tujuh) yangdiberikan SuratPeringatan (SP) I karena tidak memiliki izin. ${ }^{2}$ Di Gianyar lebih banyak lagi yaitu 30 yang disinyalir tidak memiliki kelengkapan izin; ${ }^{3}$ demikian pula di Buleleng. Ada pula toko swalayanyang melanggar izin seperti di Jembrana, buka selama 24 jam; dan di Denpasar, menjual minuman beralkohol. Asosiasi Pengusaha Ritel Indonesia (Aprindo) Bali mendukung pemerintah daerah untuk menertibkan toko swalayantidak berizin. ${ }^{4} \mathrm{Hal}$ itu disebabkan produk hukum daerah ada yang tidak sesuai dengan perkembangan peraturan perundang-undangan, misalnya Peraturan Daerah kabupaten Badung Nomor 7 Tahun 2012 tentang Penataan dan Pembinaan Pasar Tradisional, Pusat Perbelanjaan dan Toko Modern (Perda Kabupaten Badung No. 7 Tahun 2012) tidak sesuai dengan Undang-Undang Nomor 7 Tahun 2014 tentang Perdagangan (UU No. 7 Tahun 2014) dan Peraturan Menteri Perdagangan Nomor 56/M-DAG/PER/9/2014 tentang Perubahan atas Permendag No. 70/MDAG/PER/12/2013 tentang Pedoman Penataan dan Pembinaan Pasar Tradisional, Pusat Perbelanjaan dan Toko Modern. Ada pula bentuk produk hukum tidak sesuai dengan pelimpahan wewenang, misalnya Peraturan Walikota Denpasar Nomor 9 Tahun 2009 tentang Penataan dan Pembinaan Pasar Tradisional, Pusat Perbelanjaan, dan Toko Modern;bahkan ada daerah yangbelum 
memiliki produk hukum daerah yang mengatur toko swalayan yaitu Kabupaten Klungkung. Selain itu, terdapat pemasalahan inkonsistensi dalam pelaksanaan ketentuan-ketentuan tersebut, yakni toko swalayan yang tidak berizin diberkenankan tetap menjalankan usaha. Konsekuensinya yaitu tergusurnya UMKM, bahkan ada yang tutup sehingga berpengaruh terhadap perekonomian penduduk. Di situlah hukum berperan signifikan terhadap keberhasilan pembangunan ekonomi, yakni memberikan kepastian hukum atas subyek dan obyek hukum dalam setiap kegiatan ekonomi. Karenaitu, perizinan menjadi kunci utama, selain penegakan hukum, terhadap keberlanjutan, kebersamaan dan kemitraan dalam menjalankan usaha toko swalayan.

Pokok permasalahannya yaitu: bagaimanakah pengaturan perizinan toko swalayan? dan bagaimana keberadaan toko swalayan yang tidak memiliki izin?Karena itu, penelitian ini secara umum bertujuan untuk menemukan dan menganalisis bahan hukum pengaturan dan keberadaan toko swalayan di Bali. Secara khusus bertujuan untuk mengidentifikasi dan menganalisis pengaturan izin usaha toko swalayan (IUTS), dan keberadaan toko swalayan yang tidak memiliki IUTS di wilayah Provinsi Bali.

\section{Metode Penelitian}

Penelitian ini merupakan penelitian hukum normatif yang mencoba menemukan kebenaran berdasarkan logika keilmuan hukum dari sisi normatifnya ${ }^{5}$ dengan mengkaji hukum tertulis dari aspek teori, sejarah, struktur dan komposisi, lingkup dan materi, konsistensi, formalitas dan kekuatan mengikat suatu peraturan perundangundangan dan tidak mengkaji aspek terapan atau implementasinya. ${ }^{6}$ Penelitian didukung hasil wawancara dengan Bagian Hukum dan Hak Asasi Manusia; Dinas Koperasi, UMKM dan Perdagangan; dan Dinas Pariwisata Kabupaten Tabanan, Badung, dan Kota Denpasar. Selain itu, dilakukan pula diskusi dengan anggota DPRD Kabupaten Klungkung pada hari Selasa, 22 Agustus 2017. Penelitian menggunakan statutory, dan analytical or conceptualapproach terhadap bahan hukum primer, sekunder, dan tersier. Pendekatan perundang-undangan (statutory approach) digunakan dengan mengkaji produk hukum daerah yang berkaitan dengan took swalayansehingga dapat diketahui kesesuaian dan konsistensinya dengan peraturan perundangundangan yang lebih tinggi. Pendekatan konseptual atau analitis (analytical or conceptual approach) berangkat dari pendapat-pendapat atau doktrin dalam Ilmu Hukum sehingga dapat diketemukan gagasan-gagasan yang melahirkan, pengertianpengertian, konsep-konsep, dan asas-asas hukum yang relevan dengan isu yang diteliti. Bahan hukum primer, sekunder, dan tersier yang digunakan dikumpulkan dengan teknik bola salju. Bahan hukum primer dikumpulkan dengan mengikuti hierarki peraturan perundang-undangan. Bahanbahan hukum tersebutdiinventarisasi, dilakukan pengoleksian, dan diidentifikasi.Selanjutnya dilakukan klasifikasi dan interpretasi serta penyajian secara deskriptif analitis, dan akhirnya disimpulkan.

\section{Hasil dan Pembahasan \\ 3.1 Produk Hukum Daerah Terkait dengan Toko Swalayan}

Nomenklatur toko swalayan digunakan dalam UU No. 7 Tahun 2014 tentang Perdagangan. Penjelasan Pasal 12 huruf $h$ menerangkan bahwa toko swalayan" adalah toko dengan sistem pelayanan mandiri, menjualberbagai jenis barang secara eceran yang berbentuk minimarket, supermarket, departement store, hypermarket, ataupun grosir yang berbentuk perkulakan. Sebelum itu digunakan istilah toko moderndalam Pasal 1 angka 5 Peraturan Presiden Nomor 112 Tahun 2007 tentang Penataan dan Pembinaan Pasar Tradisional, Pusat Perbelanjaan dan Toko Modern (Perpres No. 112/2007), tetapi pengertiannya sama dengan pengertian toko swalayan. Kemudian, Permendag No. 56/MDAG/PER/9/2014 menentukan bahwa istilah toko modern dibaca menjadi took swalayan (Pasal II).

Pasal 12 ayat (1) huruf c Perpres 112/2007 menentukan bahwa IUTS wajib dimiliki oleh Minimarket, Supermarket, Department Store, Hypermarket dan Perkulakan. Demikian pula ketentuan Pasal 24 ayat (2) huruf c Permendag No. 56/M-DAG/PER/9/2014. Pasal 25 dan 26 menentukan bahwa kewenangan menerbitkan IUTS pada Menteri Perdagangan dapat dilimpahkan kepada Bupati, dan Bupati dapat melimpahkan kepada Kepala Dinas di bidang perdagangan atau Kepala Unit Pelayanan Terpadu Satu Pintu. Dengan demikian, pengaturan toko swalayan menjadi kewenangan pemerintahan daerah kabupaten atau kota. Sesuai dengan prinsip otonomi, maka pengaturan tersebut dilakukan dengan produk hukum daerah.

Di wilayah Provinsi Bali terdapat perbedaan produk hukum daerah untuk pengaturan toko modern. Di Kabupaten Tabanan pengaturan dilakukan dengan Perda No. 1 tahun 2016 tentang Penataan Toko Swalayan, di Kabupaten Badung dengan Perda No. 7 tahun 2012 tentang Penataan dan Pembinaan Pasar 
Tradisional, Pusat Perbelanjaan dan Toko Modern, dan dengan Perbup 10/2014 tentang Petunjuk Pelaksanaan Peraturan Daerah Kabupaten Badung Nomor 7 Tahun 2012 Tentang Penataan dan Pembinaan Pasar Tradisional, Pusat Perbelanjaan dan Toko Modern. Di Kota Denpasar pengaturan dengan Perwali No. 9 tahun 2009 tentang Penataan dan Pembinaan Pasar Tradisional, Pusat Perbelanjaan, dan Toko Modern; Keputusan Walikota No. 188.45/565/HK/2009 tentang Petunjuk Pelaksanaan Peraturan Walikota Nomor 9 Tahun 2009 tentang Penataan dan Pembinaan Pasar Tradisional, Pusat Perbelanjaan dan Toko Modern; Keputusan Walikota No. 188.45/495/ HK/2011 tentang Petunjuk Pelaksanaan Penataan dan Pembinaan Toko Modern (Mini Marker) di Kota Denpasar; dan Instruksi Walikota No. 1/ 2011: Penghentian Sementara Izin Usaha Toko Modern (Mini Market) di Kota Denpasar.

Kabupaten Klungkung belum memiliki produk hukum daerah mengenai toko swalayan. Namun bukan membiarkan toko swalayan berdiri dan berkembang tanpa pembinaan dan pengawasan. I Komang Gede Ludra, wakil ketua DPRD Klungkung, saat FGDtanggal 22 Agustus 2017 menyatakan bahwa penataan dilakukan berdasarkan UU No. 7 Tahun 2014, Perpres No. 112/2007, dan Permendag No.56/M-DAG/PER/ 9/2014.Bahkan, Bupati Klungkung, I Nyoman Suwitra menutup toko swalayan berjejaring di wilayah Banjarangkan, Klungkung pada hari Kamis, 22 September 2016, karena sudah beroperasi tetapi belum memiliki ijin. Pemilik toko terkesan main sembunyi-sembunyi, sengaja menutup logo toko menggunakan kertas putih; sedangkan ornamen lain dan struk pembelian sudah menggunakan toko berjaringan. ${ }^{7}$ Walaupun demikian, Pemerintah Daerah wajib melakukan pengaturan terhadap keberadaan toko swalayan, sebagaimana dikehendai Pasal 3 Permendag No. 56/M-DAG/PER/9/2014, bahwa pendirian toko swalayan wajib mematuhi ketentuan yang ditetapkan oleh Pemerintah Daerah setempat. Artinya bahwa Menteri Perdagangan menghendaki agar pemerintah daerah, sesuai dengan prinsip otonomi daerah, mengatur toko swalayan dengan perda berlandaskan kondisi, kebutuhan dan perilaku masyarakat. Dalam kaitan itu pantas dikemukakan pandangan Erhlich dan Rescoe Pound bahwa "hukum yang baik adalah hukum yang sesuai dengan hukum yang hidup di dalam masyarakat". 8

Pengaturan toko swalayan dengan peraturan walikota, apalagi kekosongan norma dalam produk hukum daerah, seperti di Kabupaten Klungkung, berimplikasi pada penegakan hukum atas perizinan toko swalayan. Sebab, peraturan perundang-undangan memberikan corak otoritas pada penegak hukumuntuk mengawal hukum. ${ }^{9}$ Dalam kaitan itu, Mochtar Kusumaatmaja pernah menyatakan bahwa, hukum tidak hanya sebagai seperangkat kaidah dan asas-asas yang mengatur kehidupan manusia dalam masyarakat, tetapi juga harus mencakup lembaga (institution) dan proses (process) yang diperlukan untuk mewujudkan hukum itu dalam kenyataan. Gayut dengan pendapat tersebut, J.J.H.Brugink berpendapapat bahwa sistem hukum terdiri dari tiga unsur yang saling berkaitan yakni unsur idiil, unsur operasional dan unsur aktual. ${ }^{10}$ Dengan demikian, mempercayakan pada perda sebagai pengaturan toko swalayan menunjukkan adanya kompromi sangat elegan antara bentuk hukum tertulis untuk menjamin kepastian hukum dengan living law sebagai apresiasi terhadap kebutuhan masyarakat dalam pembentukan hukum dan orientasi hukum. Pengaturan dengan perda berarti memberikan wewenang kepada otoritas penegak hukum untuk menjatuhkan sanksi pidana maupun administrasi kepada pelangar karena sudah mendapatkan legitimasi dari rakyat yang direpresentasikan dalam Dewan Perwakilan Rakyat Daerah (DPRD). Pembentukan perda sebagai wadah pengaturan toko swalayan suatu keniscayaan sebab merupakan syarat dalam pembangunan hukum nasional.

\subsection{Legalitas Toko Swalayan}

Keberadaan toko swalayan mendapatkan pengakuan secara yuridis sesuai dengan kualifikasi yang harus dipenuhi, yakni kewajiban untuk memiliki izin sebagai legalitas untuk dapat menyelenggarakan produktivitasnya. Hasil penelitian menunjukkan bahwa terdapat banyak toko swalayan, tetapi ada yang berizin dan ada pula yang tidak memiliki izin. Bahkan,legalitasnya pun berbeda-beda;seperti pada table di bawah ini.

Tabel 1: Keberadaan Toko Swalayan

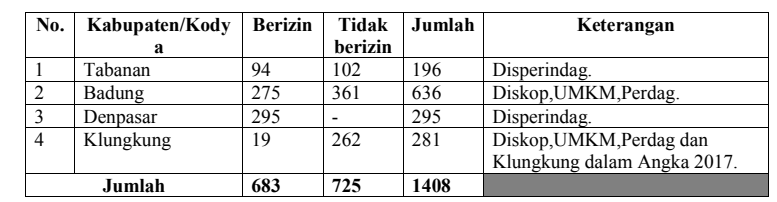

Sumber: diolah dari bahan hukum sekunder masing-masing sumber pada kolom Keterangan.

Tabel di atas menunjukan bahwa jumlah toko swalayan secara keseluruhan sebanyak 1408, sebagian besar belum memiliki izin, yaitu sebanyak 725. Sedangkan yang sudah berizin sebanyak 683 . 
Artinya bahwa yang memiliki legalitas hanya 683 , sementara sejumlah 725 belum memiliki legalitas. Toko swalayan wajib memiliki IUTS sebagai legalitas untuk dapat operasional. Sebab izin merupakan pernyataan mengabulkan atau persetujuan membolehkan. ${ }^{1}$ E. Utrecht berpendapat bahwa izin sebagai pernyataan memperkenankan melakukan perbuatan tertentu, yang pada umumnya dilarang, asalkan sesuai dengan persyaratan yang telah ditentukan. I Made Arya Utama menyatakan perizinan lebih merupakan preventif instrumental ${ }^{2}$. Philipus M Hadjon menyebutkan izin sebagai instrumen yang paling banyak digunakan oleh pemerintah untuk mengendalikan tingkah laku warga negara. ${ }^{3}$ Pasal 12 Perpres No. 112 Tahun 2007 menentukan bahwa pelaku usaha yang akan melakukan usaha toko swalayan wajib memiliki IUTS untuk Minimarket, Supermarket, Department Store, Hypermarket dan Perkulakan yang diterbitkan oleh Bupati Atau Walikota.IUTS untuk Minimarket diutamakan bagi pelaku UMKM setempat. Ketentuan tersebut ditegaskan lagi di dalam Pasal 24 dan 25 Permendag No. 56/M-DAG/PER/9/ 2014. Dengan demikian, persyaratan kepemilika izin dimaksudkan tidak sekedar agar toko swalayan dapat melaksanakan usahanya, melainkan lebih daripada itu yaitu memberikan jaminan kepastian hukum bagi eksistensi toko swalayan sehingga dapat menjalankan usahanya dengan nyaman selama masa izin berlaku. Selain itu, pemerintah daerah dapat melakukan penataaan dan pengawasan sehingga ketertiban dan keamana dalam masyarakat tidak terganggu; serta dapat melakukan penegakan hukum apabila terjadi pelanggaran terhadap ketentuan perizinan.

Hasil penelitian menunjukkan dalam produk hukum daerah ditentukan izin yang wajib dimiliki sebagai legalitas bagi pengusaha toko swalayan yaitu IUTM/S. Hal itu diilustrasikan dengan table di bawah ini.

\section{Tabel 2: Instrumen Hukum Legalitas Toko Modern}

\begin{tabular}{|l|l|l|}
\hline $\begin{array}{l}\text { Kabupaten/Kod } \\
\text { ya }\end{array}$ & $\begin{array}{c}\text { IUTM/ } \\
\text { S }\end{array}$ & \multicolumn{1}{|c|}{ Keterangan } \\
\hline Tabanan & $\sqrt{ }$ & Pasal 9 Perda 1/2016 \\
\hline Badung & $\sqrt{ }$ & Pasal 10 Perda 7/2012 \\
\hline Denpasar & $\sqrt{ }$ & Pasal 18 Perwali 9/2009 \\
\hline Klungkung & $\sqrt{ }$ & $\begin{array}{l}\text { Pasal 12 Perpres 112/2007 dan Pasal 24 Permendag No. No. } \\
\text { 70/M-DAG/PER/12/2013 jo. Permendag No. 56/M- } \\
\text { DAG/PER/9/2014. }\end{array}$ \\
\hline
\end{tabular}

Berdasarkan pada ketentuan-ketentuan dalam kolom keterangan table di atas tampak ada spesifikasi pengaturan. Di Kabupaten Tabanan, nomenklatur yang digunakan untuk penyebutan izin yaitu IUTS, karena Perda No. 1/2016 berlandaskan pada UU No. 7 Tahun 2014. Di Kabupaten Badung dan Kota Denpasar terdapat ketentuan khusus bagi IUTM Minimarket, yakni diprioritaskan bagi pelaku usaha kecil dan menengah. Nomenklatur perizinan yaitu izin usaha toko modern (IUTM) karena Perda No. 7/2012 dan Perwali No. 9/2009 menggunakan Perpres No. 112 Tahun 2007 dan Permendag No. 70/MDAG/PER/12/2013 sebagai landasan yuridisnya.Kabupaten Klungkung juga demikian karena menggunakan Perpres No. 112/2007 dan Permendag Permendag No. 56/M-DAG/PER/9/ 2014dalam penataan usaha toko swalayan.

Spesifikasi pengaturan legalitas toko swalayan sebagai akibat perbedaan landasan yuridis dan produk hukum daerah menunjukkan inkonsistensi dengan peraturan perundangundangan yang lebih tinggi. Undang-Undang Nomor 12 Tahun 2011 tentang Pembentukan Peraturan Perundang-undangan (UU No. 12 Tahun 2011) dengan tegas menentukan kekuatan hukum peraturan perundang-undangan sesuai dengan hierarkinya bahwapenjenjangan setiap jenis peraturan perundang-undangan berdasarkan pada asas bahwa peraturan perundang-undangan yang lebih rendah tidak boleh bertentangan dengan peraturan perundang-undangan yang lebih tinggi. Kosekuensi dari adanya hierarki, maka dalam pembentukan perda harus mempertimbangkan penjenjangan peraturan perundang-undangan terutama UUD 1945 sebagai hukum tertinggi. Selain itu, juga berpedoman pada Pancasila sebagai ideologi bangsa yang merupakan cita hukum Indonesia dan Norma fundamental Negara, dan asas-asas negara berdasar atas hukum dan asas-asas pemerintahan berdasar konstitusi. ${ }^{1}$ Dengan demikian, produk hukum daerah yang digunakan sebagai instrumen penataan, pembinaan dan pengawasan toko swalayan selayaknya sesuai dengan peraturan perundang-undangan yang lebih tinggi - yang di atasnya, cita hukum, serta asasasas berdasarkan atas hukum dan konstitusi.

Toko swalayan yang tidak mememiliki izin tetapi sudah operasional tetap diperkenankan menjalankan usaha dengan pertimbangan izinnya masih dalam proses, supaya tidak mematikan usaha, dan supaya tidak menimbulkan pengangguran;tetapi dilakukan pembinaan dan diawasi. Bagi yang membandel dikenakan sanksi peringatan lisan dan tertulis; sedangkan yang menyiasati - membohongi otoritas dalam pengurusan izin, maka usahanya ditutup. Dalam kaitan itu menarik dikemukakan pandangan Markus Lukman bahwa kewenangan pemerintah dalam penerbitan izin bersifat diskresionare power, dalam arti bahwa pemerintah diberikan 
kewenangan untuk mempertimbangkan dasar, materi, dan tujuan penerbitan izin berdasarkan inisiatif sendiri, misalnya memperhatikan kondisikondisi yang memungkinkan pemberian izin kepada pemohon; cara mempertimbangkan kondisi-kondisi tersebut; konsekuensi yuridis yang mungkin timbul akibat pemberian atau penolakan izin dikaitkan dengan pembatasan peraturan perundang-undangan yang berlaku; dan prosedur yang harus diikuti pada saat dan sesudah keputusan diberikan, termasuk penerimaan maupun penolakan izin. ${ }^{2}$ Dengan demikian, sikap permisif pemerintah Kabupaten Tabanan, Badung, dan Klungkung terhadap toko swalayan yang tidak berizin dapat dibenarkan secara teoritik dan demi kebutuhan praktis. Tindakan tegas yang dilakukan oleh Pemerintah Kabupaten Klungkung dan Kota Denpasar terhadap pengusaha toko swalayan yang dengan terencana sengaja mempermainkan hukum juga patut diteladani, agar tidak menimbulkan ketidakadilan dalam masyarakat.

\subsection{Persyaratan Mendirikan Toko Swalayan}

Berdasarkan ketentuan Perpres No. 112/ 2007 dan Permendag No. 56/M-DAG/PER/9/ 2014diketahui bahwa terdapat 7 (tujuh) persyaratan mendirikan toko swalayan, yaitu: persyaratan fasilitas, sosial ekonomi, luas lantai, sistem penjualan dan barang yang dijual, lokasi, jarak, dan jam kerja. Hasil penelitian menunjukkan bahwa terdapat perbedaan persayaratan fasilitas untuk mendirikan toko swalayan antara di Kabupaten Tabanan disatu pihak dengan di Kabupaten Badung, Kota Denpasar, dan Kabupaten Klungkung pada pihak lain. Pemerintah Kabupaten Tabanan menentukan adanya satu persyaratan yang bersifat umum - kurang konkret yaitu ketersediaan fasilitas sosial dan fasilitas umum. Selain itu ada persyaratan khusus yakni penyediaan fasilitas untuk difabel (Pasal 5 hurufg dan Pasal 12 hurufh Perda 1/2016). Sementara itu, terdapat persamaan persyaratan yang ditentukan oleh Kabupaten Badung, Kota Denpasar, dan Kabupaten Klungkungyaitu mewajibkan menyediakan:areal parkir paling sedikit seluas kebutuhan parkir 1 (satu) unit kendaraan roda empat untuk setiap $60 \mathrm{~m} 2$ (enam puluh meter per segi) luas lantai penjualan toko swalayan; danfasilitas yang menjamin kebersihan, sehat (hygienis), aman, tertib dan ruang publik yang nyaman (Pasal 2 Perda 7/2012, Pasal 4 Perwali 9/2009, Pasal 4 Perpres 112/2007).

Pengaturan persyaratan sosial ekonomi mendirikan toko swalayan terdapat dua pola yaitu pertama, membedakan persyaratan sosial ekonomi untuk Supermarket, Department Store,
Hypermarket, dan Perkulakan dengan persyaratan untuk minimarket. Hal itu terdapat di Kabupaten Tabanan, Badung, dan Kota Denpasar. Pola kedua, dilakukan oleh Kabupaten Klungkung, yakni menyamakan persyaratan sosial ekonomi untuk semua bentuk toko swalayan (Pasal 4 Permendag No. 56/M-DAG/PER/9/2014). Persyaratan sosial ekonomi untuk Supermarket, Department Store, Hypermarket, dan Perkulakan serta Minimarket (khusus di Klungkung) merujuk pada Pasal 4 Permendag No. 56/M-DAG/PER/ 9/2014, yaitu:

a. struktur penduduk menurut mata pencaharian dan pendidikan;

b. tingkat pendapatan ekonomi rumah tangga;

c. tingkat kepadatan dan pertumbuhan penduduk di masing-masing daerah sesuai dengan data sensus Badan Pusat Statistik (BPS) tahun terakhir;

d. rencana Kemitraan dengan UMKM;

e. penyerapan tenaga kerja;

f. ketahanan dan pertumbuhan pasar rakyat sebagai sarana bagi UMKM;

g. ketersediaan fasilitas sosial dan fasilitas umum;

h. dampak positif dan negatif atas pendirian toko swalayan terhadap pasar rakyat atau toko eceran yang telah ada sebelumnya; dan

i. tanggungjawab sosial perusahaan (Corporate Social Responsibility) yang diarahkan untuk pendampingan bagi pengelolaan pasar rakyat.

Tetapi, di Kabupaten Tabanan, Badung, dan Kota Denpasar persyaratan nomor c tersebut di atas dipilah menjadi dua, yaitu: kepadatan penduduk, dan pertumubuhan penduduk.

Pengaturan persyaratan luas lantai penjualan toko swalayan dalam produk hukum daerah di Kabupaten Tabanan, Badung, dan Klungkung menunjukkan adayakesamaan, yakni: Minimarket, kurang dari $400 \mathrm{M}^{2}$; Supermarket, lebih dari $400 \mathrm{M}^{2}$; Department Store, lebih dari $400 \mathrm{M}^{2}$; Hypermarket, lebih dari $5.000 \mathrm{M}^{2}$; dan Perkulakan, lebih dari $5.000 \mathrm{M}^{2}$.Tetapi terdapat satu perbedaan yaitu di Kabupaten Tabanan, Badung dan Kota Denpasar luas lantai Supermarket dibatasi antara 400 M2 sampai dengan $5,000 \mathrm{M}^{2}$, sehingga berbeda dengan luas lantai penjualan untuk Department Store yaitu lebih dari $400 \mathrm{M}^{2}$. Artinya,luas lantai penjualan Department Store tidak mencapai 5,000 $\mathrm{M}^{2}$. Sebab jika suatu Department Store memiliki luas lantai mencapai 5,000 $\mathrm{M}^{2}$, maka pelaku usaha tersebut tidak dapat lagi disebut Department Store, melainkan Supermarket (Pasal 8 Perda 1/2016, Pasal 5 Perda 7/2012, Pasal 6 Permendag No. 70/M-DAG/PER/12/2013). Kota Denpasar menetapkan klasifikasi persyaratan luas lantai 
penjualan berdasarkan pada sumber modalnya, sehingga terdapat perbedaan persyaratan toko swalayan dengan modal $100 \%$ dalam negeri dan yang tidak $100 \%$ dalam negeri. Persyaratan luas lantai penjualan toko swalayan dengan modal tidak $100 \%$ dalam negeri yaitu: Minimarket, kurang dari $400 \mathrm{M}^{2}$; Supermarket, Toko Serba Ada, Swalayan $400 \mathrm{M}^{2}-5.000 \mathrm{M}^{2}$; Hypermarket, di atas $5.000 \mathrm{M}^{2}$; Department Store dan Mall, di atas $400 \mathrm{M}^{2}$; dan Perkulakan, di atas $5.000 \mathrm{M}^{2}$. Sedangkan toko swalayan dengan modal 100\% dalam negeri ditentukan denganpersyaratan luas lantai: Minimarket, kurang dari $400 \mathrm{M}^{2}$; Supermarket, Toko Serba Ada, Swalayan, kurang dari $1.200 \mathrm{M}^{2}$; dan Department Store, kurang dari $2.000 \mathrm{M}^{2}$ (Pasal 3 (3), (4) Perwali 9/2009).

Persyaratan sistem penjualan dan barang yang dijual di Kabupaten Tabanan, Badung, Kota Denpasar, dan Kabupaten Klungkung sama sebab sama-sama merujuk pada Pasal 7Permendag 56/ M-DAG/PER/9/2014. Persyaratan tersebut diilustrasikan dengan table di bawah ini.

\section{Tabel 3. Persyaratan Sistem Pejualan dan Barang yang dijual.}

\begin{tabular}{|l|l|l|l|}
\hline No & \multicolumn{1}{|c|}{$\begin{array}{c}\text { Toko } \\
\text { Swalayan }\end{array}$} & \multicolumn{1}{|c|}{$\begin{array}{c}\text { Sistem } \\
\text { Penjualan }\end{array}$} & \multicolumn{1}{c|}{ Barang yang dijual } \\
\hline 1 & Minimarket & Eceran & $\begin{array}{l}\text { Barang konsumsi terutama produk makanan } \\
\text { dan produk rumah tangga lainnya. }\end{array}$ \\
\hline 2 & Supermarket & Eceran & Sama dengan Minimarket \\
\hline 3 & Hypermarket & Eceran & Sama dengan Minimarket \\
\hline 4 & $\begin{array}{l}\text { Departement } \\
\text { store }\end{array}$ & Eceran & $\begin{array}{l}\text { Produk sandang dan perlengkapannya. } \\
\text { Penataan barang berdasarkan jenis kelamin } \\
\text { dan/atau tingkat usia konsumen. }\end{array}$ \\
\hline 5 & Perkulakan & Grosir & Barang konsumsi \\
\hline
\end{tabular}

Sumber: Diolah dari ketentuanPasal 1 angka 17, 19, 20, 22, 23 Perda 1/2016, Pasal 6 Perda 7/2012, Pasal 3 (5) Perwali 9/ 2009, Pasal 7 Permendag No. 70/M-DAG/ PER/12/2013.

Tabel di atas memperlihatkan bahwa pengaturan persyaratan sistem penjualan dan barang yang dijual oleh toko swalayan dalam produk hukum daerah sinkron dengan peraturan perundang-undangan di atasnya. Sinkronisasi peraturan perundang-undangan secara vertikal menjadi syarat mutlak sebagaimana ditentukan dalam Pasal 7 UU No. 12 Tahun 2011.Sinkronisasi tersebut tidak hanya sebatas sinkronisasi terhadap sistematika hukum, yakni sinkronisasi peraturan perundang-undangan secara hierarkis; tetapi jugasinkronisasi terhadap asas-asas peraturan perundang-undangan. ${ }^{1}$

Persyaratan lokasi mendirikan toko swalayan, diklasifikasikan menjadi dua, yaitu persyarat umum dan persyaratan khusus. Persyaratan umum terdapat persamaan, yaitu: wajib mengacu pada RTRW, dan RDTR, termasuk Peraturan Zonasinya serta harus memperhatikan persyaratan lokasi pada sistem jaringan jalan di daerah. Namun di Kabupaten Klungkung persyaratan tersebut hanya satu, yakni mengacu pada RTRW Kabupaten/Kota, dan RDTR. Persyaratan khusus terdapat dua kelompok. Di Kabupaten Tabanan, persyaratan khusus dirumuskan secara umum utnuk dua kategori yaitu untuk minimarket, di satu pihak; dan untuk Supermarket, Department Store, Hypermarket, dan Grosir/Perkulakan. Persyaratan khusus tersebut yaitu:

a. Minimarket berjejaring, hanya dapat dilakukan di tepi jalan kolektor primer dan jalan arteri.

b. Supermarket, Department Store, Hypermarket, dan Grosir/Perkulakan, hanya boleh berlokasi pada sistem jaringan jalan arteri.

Di Kabupaten Badung dan Kota Denpasar, persayaratan khusus diformulasikan secara spesifik untuk masing-masing bentuk toko swalayan. Hal itu tampak pada tabel sebagai berikut:

\section{Tabel 4: Persyaratan Lokasi Toko Swalayan di Kabupaten Badung dan Kodya Denpasar}

\begin{tabular}{|l|l|l|}
\hline No. & Toko Swalayan & \multicolumn{1}{c|}{ Lokasi } \\
\hline 1 & Perkulakan & $\begin{array}{l}\text { Pada akses sistem jaringan jalan arteri atau kolektor primer atau } \\
\text { sekunder. }\end{array}$ \\
\hline 2 & $\begin{array}{l}\text { Hypermarket dan } \\
\text { Pusat } \\
\text { Perbelanjaan }\end{array}$ & $\begin{array}{l}\text { a. Pada akses sistem jaringan jalan arteri atau kolektor. } \\
\text { b. Tidak boleh berada pada kawasan pelayanan lokal atau } \\
\text { lingkungan di dalam kota/perkotaan. }\end{array}$ \\
\hline 3 & $\begin{array}{l}\text { Supermarket, } \\
\text { Swalayan dan } \\
\text { Departement } \\
\text { Store }\end{array}$ & $\begin{array}{l}\text { a. Tidak boleh berlokasi pada sistem jaringan jalan lingkungan. } \\
\text { b. Tidak boleh berada pada kawasan pelayanan lingkungan di } \\
\text { dalam kota/perkotaan. }\end{array}$ \\
\hline 4 & $\begin{array}{l}\text { Minimarket } \\
\text { lada setiap sistem jaringan jalan, termasuk sistem jaringan jalan } \\
\text { lingkungan pada kawasan pelayanan lingkungan (perumahan) di } \\
\text { dalam kota/perkotaan. }\end{array}$ \\
\hline
\end{tabular}

Persyaratan jarak lokasi mendirikan toko swalayan dengan pasar rakyat dan antar-toko swalayan ditentukan oleh pemerintah daerahmasing-masing dengankriteria tersendiri. Pemerintah Daerah kabupaten Tabanan menggunakan luas lantai penjualan sebagai dasar menentukan jarak toko swalayan, sebagai berikut.

\section{Tabel 5. Jarak Lokasi Toko Swalayan di Kabupaten Tabanan}

\begin{tabular}{|l|l|}
\hline \multicolumn{1}{|c|}{ Toko Modern } & \multicolumn{1}{c|}{ Jarak } \\
\hline $\begin{array}{l}\text { Minimarket luas lantai penjualan 200M } \\
\text { dan bukan minimarket berjejaring }\end{array}$ & $\begin{array}{l}\text { Paling dekat radius 500 M dari pasar rakyat } \\
\text { dan minimal 50 M dari minimarket lainnya. }\end{array}$ \\
\hline $\begin{array}{l}\text { Minimarket luas lantai penjualan 200M } \\
\text { dan semua minimarket berjejaring }\end{array}$ & $\begin{array}{l}\text { Paling dekat radius 2000 M dari pasar rakyat } \\
\text { dan minimal 250 M dari minimarket lainnya. }\end{array}$ \\
\hline Supermarket dan Department Store & $\begin{array}{l}\text { Paling dekat radius 2000 M dari pasar rakyat } \\
\text { dan minimal 1000 M dari Supermarket dan } \\
\text { Department Store lainnya. }\end{array}$ \\
\hline Hypermarket dan Perkulakan & $\begin{array}{l}\text { Paling dekat dalam radius 2500 M dari pasar } \\
\text { rakyat dan minimal 1000 M dari Supermarket, } \\
\text { Department Store, hypermarket, dan } \\
\text { perkulakan. }\end{array}$ \\
\hline
\end{tabular}

Kabupaten Badung menentukan jarak lokasi toko swalayan berdasarkan kawasan, yakni: kawasan Badung Utara, jarak sejauh 1.000 Meter;di kawasan Badung Tengah 700 Meter; dan 
Kawasan Badung Selatan sejauh 500 Meter. Kota Denpasar menentukan jarak lokasi toko swalayan, selain minimarket, yakni:

a. Tidak diperkenankan pada radius kurang dari 1 (satu) kilo meter dari pasar rakyat, pusat perbelanjaan dan/atau toko swalayan yang sudah ada.

b. Paling kurang pada jarak $250 \mathrm{M}$ dari persimpangan jalan dan/atau trafic light.

Sementara itu, Kabupaten Klungkung belum menentukan persyaratan jarak mendirikan toko swalayan, sebab belum memiliki produk hukum daerah mengenai toko swalayan. Dalam hal itu, Pemerintah Daerah Kabupaten Klungkung seharusnya tidak perlu menunggu membentuk perda untuk menentukan persyaratan jarak lokasi toko swalayan, tetapi dapat menetapkan berdasarkan peraturan bupati. Sebab sesuai dengan teori diskresi atau discretion (Inggris), discretionair (Perancis), freies ermessen (Jerman) dan sudah ditentukan pula dalam Undang-Undang Nomor 30 Tahun 2014 tentang Administrasi Pemerintahan, pemerintah daerah memiliki kebebasan untuk bertindak atas inisiatif sendiri, tetapi dalam pelaksanaan haruslah sesuai dengan hukum, sebagaimana telah ditetapkan dalam negara hukum berdasarkan Pancasila. Kemerdekaan bertindak tersebut dimaksudkan untuk menyelesaikan masalah yang timbul dalam masyarakat, terutama pelaku UMKM mempermasalahkan keberadaan toko swalayan, sementara itu peraturan penyelesaian untuk masalah itu belum ada ${ }^{1}$.

Pengaturan persyaratan jam kerja toko swalayanterdapat persamaan, kecuali Kabupaten Tabanan menentukan jam kerja secara umum, dan di Kabupaten Badung ada persyaratan jam kerja untuk minimarket. Persyaratan jam kerja Hypermarket, Department Store, Supermarket, dan Toko Serba Ada yaitu:

a. Senin - Jumat, pukul 10.00 WITA - 22.00 WITA.

b. Sabtu dan Minggu pukul 10.00 WITA - 23.00 WITA.

c. Hari besar keagamaan, libur nasional atau hari tertentu lainnya, Bupati/Walikota dapat menetapkan jam kerja melampaui pukul 22.00 WITA.

Kabupaten Tabanan menetapkan jam kerja toko swalayan yaitu:

a. Waktu buka minimal pukul 10.00 WITA dan waktu tutup maksimal pukul 22.00 WITA.

b. Hari besar keagamaan, libur nasional atau hari tertentu lainnya dapat menetapkan jam kerja melampaui pukul 22.00 waktu setempat atas seijin BPMPD.
Kabupaten Badung, satu-satunya yang menetapkan persyaratan jam kerja bagi minimarket, yaitu: dapat beroperasi 24 (dua puluh empat) jam, jika mendapatkan izin dari Bupati, dengan syarat: berada dalam kawasan pariwisata dalam radius paling jauh 1.000 meter dari pusat kawasan pariwisata, dan melampirkan rekomendasi dari Lurah/Perbekel yang diketahui oleh Camat.

\subsection{Sanksi atas Pelanggaran Perizinan Toko Swalayan}

Perpres No. 112 Tahun 2007 dan Permendag 56/M-DAG/PER/9/2014tidak menentukan sanksi terhadap pelaku usaha yang tidak memiliki izin. Pasal 17 mengatur sanksi administratif yaitu peringatan tertulis, pembekuan dan pencabutan izin usaha atas pelanggaran terhadap Pasal 6, Pasal 7 ayat (1) dan ayat (2), Pasal 8 ayat (3), Pasal 9, Pasal 10 ayat (2) dan Pasal 16. Di situ tidak ada ketentuan sanksi atas pelanggaran terhadap Pasal 12, yakni kewajiban untuk memiliki izin bagi pelaku usaha yang melakukan usaha toko swalayan. Pasal 12 dengan tegas mewajibkan adanya izin untuk dapat melakukan usaha took swalayan, sebagai berikut:

a. Izin Usaha Pusat Perbelanjaan (IUPP) untuk Pertokoan, Mall, Plasa dan Pusat Perdagangan.

b. Izin Usaha Toko Swalayan (IUTS) untuk Minimarket, Supermarket, Department Store, Hypermarket dan Perkulakan.

Jenis Norma dalam Pasal 12 yaitu Norma perintah, sebagai salah satu Norma imperatif yang mengatur perilaku subyek hukum dalam masyarakat ${ }^{2}$. Norma tersebut mengharus pelaku usaha untuk memiliki izin usaha sesuai dengan bidang usahanya sehingga usaha yang dijalankan memiliki legalitas. Sebaliknya, jika pelaku usaha menjalankan tanpa memiliki IUTS, maka usahanya itu ilegal sehingga dapat ditutup. Jika usaha yang ilegal itu dibiarkan tetap operasional, dapat menimbulkan ketidaktertiban dalam masyarakat. Itu berarti Norma hukum tidak efektifkarena tidak ditegakkan. Padahal Norma hukum itu sangat diperlukan sebab tidak semua kepentingan telah diatur di dalam Norma agama, susila, dan kesopanan untuk dapat menjadikan masyarakat tertib. ${ }^{3}$ Selain itu, inti suatu Norma yaitu segala aturanyang harus dipatuhi ${ }^{4}$, sehingga pelaku usaha tidak luput dari Norma tersebut.

Sanksi terhadap toko swalayan yang melanggar ketentuan perizinan pada prinsipnya sama secara normatif maupun dalam praktik. Secara normatif sanksi terdiri atas sanksi administratif dan sanksi pidana. Sanksi 
administratif, terutama di Kabupaten Tabanan dan Badung, terdiri atas peringatan tertulis, pembekuan izin, dan pencabutan izin yang dilakukan secara bertahap (Pasal 14 Perda 1/2016 dan Pasal 22 Perda 7/2012). Kota Denpasar tidak menentukan adanya sanksi tersebut karena pengaturan dengan Perwli. Sanksi pidana untuk di Kabupaten Tabanan yaitu kurungan paling lama 3 bulan atau denda paling banyak Rp. 50 juta (Pasal 17 Perda 1/2016), sedangkan di Kabupaten Badung berupa kurungan paling lama 6 bulan atau denda paling banyak Rp. 50 juta (Pasal 24 Perda 7/2012). Dalam praktik, penjatuhan sanksi yang dilakukan oleh Kabupaten Tabanan dalam bentuk peringatan tertulis; di Badung dilakukan peringatan tertulis dan penertiban; di Denpasar berupa pembinaan, pengawasan, dan penyegelan. Sedangkan Klungkung menutup toko swalayan.

\subsection{Dampak Keberadaan Toko Swalayan Terhadap Kepariwisataan}

Hasil penelitian menunjukkan bahwa keberadaan toko swalayan mendukung kepariwisataan, walaupun dapat juga dinyatakan sebagai penyebab tidak langsung atas dampak kurang baik terhadap kepariwisataan. ${ }^{5}$ Toko swalayan berpotensi mendukung kepariwisataan berakar pada keunggulan yang dimiliki, antara lain: 1. Mudah diketemukan.

Toko swalayan tersebar nyaris hingga ke setiap desa, menggunakan teknologi maju - IT dalam mempromosikan produknya sehingga sangat mudah diketahui dan diketemukan oleh konsumen (termasuk wisatawan).Di obyekobyek wisata sangat mudah menemukan gerai atau outlet yang menyajikan barang-barang konsumsi yang dibutuhkan oleh wisatawan.

2. Memberikan kenyamanan dan keamanan.

Toko swalayan menjamin adanya kenyamanan dan keamanan, sebagai kondisi vital bagi wisatawan bahkan juga bagi siapa saja dalam berbelanja. Adanya pendingin udara yang sejuk, bersih, tidak ada bau tidak sedap, tidak berdesak-desakan, dan display barang perkatagori mudah dicapai serta relatif lengkap.

3. Menyediakan berbagai barang dengan kualitas terjamin.

Dalam toko swalayan, barang yang dijual memiliki variasi jenis yang beragam; menyediakan barang lokal, dan juga menyediakan barang impor. Selain bahan makanan seperti: buah, sayuran, daging, sebagian besar barang lain yang dijual yaitu barang yang dapat bertahan lama; bahkan di toko swalayan tertentu bisa didapatkan minuman beralkohol. Dari segi kualitas, barang yang dijual mempunyai kualitas yang relatiflebih terjamin karena melalui seleksi dan pengawasan yang ketat secara rutin oleh otoritas sehingga barang yang tidak memenuhi kualifikasi dan klasifikasi akan di tolak serta barang yang sudah kedaluwarsa (expired datet) dikeluarkan dari toko.

4. Mencantumkan tarif-label harga yang pasti dan harga barang relatif terjangkau.

Barang-barang yang dijual di toko swalayan sudah memiliki label harga yang pasti. Di sini penjual dan pembeli tidak bertransaksi secara langsung, pembeli cukup melihat label harga yang tercantum dalam bar code sehingga sudah bisa memutuskan untuk bertransaksi atau tidak. Orang yang berbelanja terlebih dahulu pasti ingin mengetahui harganya-melihat harga lebih dahulu sebelum memutuskan untuk membeli. Semakin murah harga dan kualitas terjamin maka semakin besar peluang barang akan dibeli.

5. Pelayanan yang baik.

Toko swalayan memberikan pelayanan yang baik, tampak misalnya dengan adanya pendingin, display barang perkategori mudah dicapai dan relatif lengkap, informasi produk tersedia melalui mesin pembaca, adanya keranjang belanja atau keranjang dorong. Selain itu adanya kasir dan pramuniaga yang bekerja secara professional, jam buka yang lebih panjang, dan memfasilitasi aneka pilihan pembayaran antara lain kartu kredit.

Informan juga menyatakan bahwa keberadaan toko swalayan merupakan salah satu penyebab tidak langsung terhadap tergganggunya ketertiban dalam masyarakat yang ditimbulkan oleh orang mabuk. Selain itu, kerap terjadi anakanak atau remaja di bawah umur mengkonsumsi minuman beralkohol karena bisa mendapatkan di toko swalayan. Dikatakan sebagai penyebab tidak langsung karena konsumen dengan mudah dapat membeli minuman beralkohol, termasuk remaja di bawah umur karena pengawasan oleh pramuniaga kurang. Sebagai akibat penyalahgunaan minuman beralkohol, mereka lalu mabuk dan eksesnya kerap terjadi perkelahian - menimbulkan keributan di masyarakat, bahkan dapat tertjadi tindakan kriminalitas.

\section{Kesimpulan dan Rekomendasi}

Berdasarkan pada paparan hasil penelitian tersebut di atas maka disimpulkan dan direkomendasikan sebagai berikut:

Pengaturan izin toko swalayandilakukan berdasarkan produk hukum daerah. Hal itu sesuai dengan pelimpahan wewenang Menteri kepada 
Kepala Daerah sebagaimana ditentukan dalam Permendag No. 56/M-DAG/PER/9/2014. Namun di daerah terdapat berbagai produk hukum yang dijadikan sebagai dasar penerbitan izin toko swalayan, seperti Peraturan Daerah Kabupaten Tabanan No. 1 Tahun 2016, Peraturan Daerah Kabupaten Badung No. 3 Tahun 2017, dan Peraturan Walikota Denpasar No. 9 Tahun 2009. Bahkan Kabupaten Klungkung belum memiliki produk hukum daerah sebagai dasar penerbitan izin. Legalitas operasional toko swalayan secara normatif berbentuk IUTS - di Kota Denpasar disebut IUTM, IUPP, DUTS, dan DUPP. Namun di dalam praktek, seperti Kabupaten Tabanan dan Klungkung masih menggunakan SIUP dan TDP. Perilaku pelaku usaha toko swalayan yang dikualifikasi sebagai pelanggaran hukum yang ditentukan dalam produk hukum daerah pada prinsipnya merupakan pelangaran terhadap persyaratan mendirikan toko swalayan dan larangan bagi toko swalayan. Namun di dalam praktik pelanggaran yang dilakukan yaitu pelanggaran jam kerja, pelanggaran jarak lokasi, pelanggaran tidak memiliki IUTS, tidak mengajukan permohonan izin baru dalam memindahkan lokasi, dan menjual barang dagangan yang tidak sesuai dengan izin.

Penegakan hukum terhadap pelanggaran atas perizinan toko swalayan, secara normatif dilakukan dengan menjatuhkan sanksi administratif, sanksi pidana atau denda. Dalam praktik penegakan hukum dilakukan dengan memberikan peringatan lisan, peringatan tertulis, pembinaan, mengajukan izin, dan pembekuan usaha. Toko swalayan yang tidak memiliki izin diberikan kesempatan menjalankan usaha dengan pertimbangan bahwa izin sedang dalam proses, perpanjangan izin, tidak mematikan usaha, dan tidak menambah banyak pengangguran. Namun yang membandel, diberikan peringatan lisan dan tertulis; bahkan dengan menutup usahanya.

Sehubungan dengan terdapat beragam produk hukum daerah mengenai toko swalayan, maka Pemerintahan Daerah di wilayah Provinsi Bali sebaiknya melakukan pengaturan toko swalayan dengan Peraturan Daerah. Pemerintah Daerah Kabupaten Klungkung sebaiknya segera membentuk Perda mengenai toko swalayan. Keberadaan toko swalayan yang belum memiliki izin supaya dimonitoring dan dievaluasi mengenai kemajuan pengurusan izinnnya, dan diidentivikasi toko swalayan yang izinnya sudah terbit. Penegakan hukum hendaknya dilakukan dengan tegas dan konsisten sesuai dengan peraturan perundang-undangan terhadap toko swalayan yang belum mengajukan permohonan izin tetapi sudah operasional agar tidak menimbulkan ketidakadilan dalam masyarakat.

\section{Daftar Pustaka / Daftar Referensi}

\section{Produk Hukum:}

Undang-Undang Nomor 7 Tahun 2014 tentang Perdagangan, Lembaran Negara Tahun 2014 Nomor 45, Tambahan Lembaran Negara Nomor 5512.

Peraturan Presiden Republik Indonesia Nomor 112 Tahun 2007 tentang Penataan dan Pembinaan Pasar Tradisional, Pusat Perbelanjaan dan Toko Modern.

Peraturan Menteri Perdagangan Nomor 56/MDAG/PER/9/2014 tentang Perubahan atas Permendag No. 70/M-DAG/PER/12/2013 tentang Pedoman Penataan dan Pembinaan Pasar Tradisional, Pusat Perbelanjaan dan Toko Modern.

Peraturan Daerah Kabupaten Tabanan Nomor 1 tahun 2016 tentang Penataan Toko Swalayan.

Peraturan Daerah Kabupaten Badung Nomor. 7 tahun 2012 tentang Penataan dan Pembinaan Pasar Tradisional, Pusat Perbelanjaan dan Toko Modern.

Peraturan Bupati Badung Nomor 10 Tahun 2014 tentang Petunjuk Pelaksanaan Peraturan Daerah Kabupaten Badung Nomor 7 Tahun 2012 Tentang Penataan dan Pembinaan Pasar Tradisional, Pusat Perbelanjaan dan Toko Modern.

Peraturan Walikota Denpasar Nomor 9 tahun 2009 tentang Penataan dan Pembinaan Pasar Tradisional, Pusat Perbelanjaan, dan Toko Modern.

Keputusan Walikota Denpasar Nomor 188.45/ 565/HK/2009 tentang Petunjuk Pelaksanaan Peraturan Walikota Nomor 9 Tahun 2009 tentang Penataan dan Pembinaan Pasar Tradisional, Pusat Perbelanjaan dan Toko Modern.

Keputusan Walikota Denpasar Nomor 188.45/ 495/HK/2011 tentang Petunjuk Pelaksanaan Penataan dan Pembinaan Toko Modern (Mini Marker) di Kota Denpasar. Instruksi Walikota Denpasar Nomor 1 Tahun 2011 tentang Penghentian Sementara Izin Usaha Toko Modern (Mini Market) di Kota Denpasar. 
Buku:

Departemen Pendidikan dan Kebudayaan. (1995). Kamus Besar Bahasa Indonesia, Edisi Kedua. Jakarta: Balai Pustaka.

Ibrahim, Jhony. (2005). Teori dan Metodelogi Penelitian Hukum Normatif. Malang: Bayu Media Publishing.

Muhamad, A K. (2004). Hukum dan Penelitian Hukum. Bandung: Citra Aditya Bakti.

Salman, Otje. (2009). Filsafat Hukum (Perkembangan \& Dinamika Masalah). Cetakan Pertama. Bandung: PT Refika Aditama.

Suantra, I Nengah dkk. (2015). Buku Ajar dan Klinik Manual Klinik Perancangan Produk Hukum Daerah, Kerjasama Fakultas Hukum Universitas Udayana dengan USAID From The American People dan The Asia Foundation, Cetakan Pertama. Denpasar: Udayana University Press.

Jurnal:

Ferry Irawan Febriansyah. (2016). Konsep Pembentukan Peraturan Perundangundangan di Indonesia Perspektif, Vol. XXI: 3.

Jayantara, M. (2015). Instrumen Rekomendasi DPRD Dalam Penyelenggaraan Kewenangan Perijinan Oleh Pemerintah Daerah. Jurnal Magister Hukum Udayana (Udayana Master Law Journal), 4 (3).

Jurnal KAPemda - Kajian Administrasi dan Pemerintahan Daerah. (2017). Volume 10 No. 6/Maret 2017.

Lisya Wandasari, Shandra. (2013). "Sinkronisasi Peraturan Perundang-Undangan dalam Mewujudkan Pengurangan Risiko Bencana”. Unnes Law Journal 2 (2).

Markus Lukman. (1996). Eksistensi Peraturan Kebijakan dalam Bidang Perencanaan dan Pelaksanaan Rencana Pembangunan di Daerah Serta Dampaknya Terhadap Pembangunan Materi Hukum Tertulis Nasional, Disertasi, Universitas Padjajaran, Bandung.

M. Hadjon,Philipus. (1993). Pengantar Hukum Perizinan. Jurnal Yuridika. Surabaya.

Subadidan Tiara Oliviarizky Toersina. (2018). "Perkembangan Konsep atau Pemikiran Teoritik tentang Diskresi Berbasis
Percepatan Investasi di Daerah". MIMBAR HUKUMVolume 30 (1).

Online/World Wide Web:

Bali Tribune. (2016). "Tim Yustisi Karangasem Sidak Toko Swalayan - Alfa Mart Tak Berizin Terancam Disegel", http:// balitribune.co.id/content/tak-berizinindomaret-di-sidemen-disegel.

Damang. (2016) "Pengertian Perizinan", http:// www.negarahukum.com/hukum/pengertianperizinan.html.

Mahendra, P.A. (2016). "Beroperasi 24 Jam Indomart Gilimanuk Disegel Satpol PP," http://balitribune.co.id/content/beroperasi24-jam-indomart-gilimanuk-disegel-satpolpp.

NusaBali. (2016)."Badung Hanya Butuh 1.760 Toko Swalayan", http://www.nusabali.com/ berita/6486/badung-hanya-butuh-1760toko-swalayan.

Kristianto,Feri.Editor: Miftahul Ulum. (2017). "Pemda di Bali Diminta Konsisten Tertibkan Toko Swalayan".http://bali.bisnis.com/read/ 20170531/16/66810/pemda-di-balidiminta-konsisten-tertibkan-toko-swalayan . san sumber online: nama belakang penulis , singkatan dari nama depan . dalam tanda kurung tahun . Judul artikel . Retrieved from nama website.

Jul. 22 September 2016, "Tidak Kantongi Ijin, Toko Modern di Klungkung Ditutup", https:/ /suaradewata.com/read/2016/09/22/ 201609220017/Tidak-Kantongi-IjinToko-Modern-di-Klungkung-Ditutup.html. 